\title{
PENINGKATAN HASIL BELAJAR IPS MELALUI MODEL PEMBELAJARAN KOOPERATIF TEKNIK THINK PAIR SHARE DI SEKOLAH MENENGAH PERTAMA
}

\author{
Nurhayati \\ Guru SMP Negeri 1 Peureulak Barat \\ pnurhayati988@gmail.com
}

\begin{abstract}
This study aims to improve student learning outcomes through the application of Think Pair Share Technique Cooperative Learning Model Students of Class IX Middle School 1 Peureulak Barat semester II of the academic year 2017/2018. This research is a classroom action research (CAR) carried out in two cycles, in each cycle, the researcher used several research procedures including, planning, implementing, observing and reflecting. Data collection techniques used in research include, observation of teacher activities, student activities, and student learning outcomes tests, which are used to determine student learning outcomes after an action is taken. Student learning outcomes can be declared successful when learning outcomes have reached KKM of 70. Classically a class has been completed learning when classical completeness reaches $85 \%$ with the application of the Think Pair Share Cooperative Learning Model Technique. The results showed, in the first cycle the average value of students amounted to 65.2 and mastery learning reached $40 \%$. These results indicate an improvement from the initial conditions with an average score of only 52 and completeness of learning only 20\%. While in cycle II the average value of students was 82.4 and mastery learning reached $92 \%$. The conclusion of this study is the application of Think Pair Share Cooperative learning model can improve social studies learning outcomes of international trade class IX second semester students of SMP Negeri 1 Peureulak Barat, East Aceh Regency.
\end{abstract}

Keywords: Social Studies Learning Outcomes, International Trade Material, and Cooperative Learning Models Think Pair Share Techniques

\begin{abstract}
ABSTRAK
Penelitian ini bertujuan untuk meningkatkan hasil belajar siswa melalui penerapan Model Pembelajaran Kooperatif Teknik Think Pair Share Siswa Kelas IX SMP Negeri 1 Peureulak Barat semester II tahun pelajaran 2017/2018. Penelitian ini merupakan penelitian tindakan kelas (PTK) yang dilaksanakan dalam dua siklus, pada masing-masing siklus, peneliti menggunakan beberapa prosedur penelitian meliputi, perencanaan, pelaksanaan, pengamatan dan refleksi. Teknik pengumpulan data yang digunakan dalam penelitian meliputi, observasi aktivitas guru, aktivitas siswa, dan tes hasil belajar siswa, yang digunakan untuk mengetahui hasil belajar siswa setelah dilakukan tindakan. Hasil belajar siswa dapat dinyatakan berhasil bila hasil belajar telah mencapai KKM sebesar 70. Secara klasikal suatu kelas telah tuntas belajar bila ketuntasan klasikal mencapai 85\% dengan diterapkannya Model Pembelajaran Kooperatif Teknik Think Pair Share. Hasil penelitian menunjukkan, pada siklus I nilai rata-rata siswa berjumlah 65,2 dan ketuntasan belajar mencapai $40 \%$. Hasil ini menunjukkan peningkatan dari kondisi awal yang nilai rata-ratanya hanya 52 dan ketuntasan belajar baru $20 \%$. Sedangkan pada siklus II nilai rata-rata siswa 82,4 dan ketuntasan belajar mencapai 92\%. Kesimpulan dari penelitian ini adalah penerapan model pembelajaran Kooperatif Teknik Think Pair Share dapat meningkatkan hasil belajar IPS materi perdagangan internasional siswa kelas IX semester II SMP Negeri 1 Peureulak Barat Kabupaten Aceh Timur.
\end{abstract}

Kata Kunci: Hasil Belajar IPS, Materi Perdagangan Internasional, dan Model Pembelajaran Kooperatif Teknik Think Pair Share

\section{Author correspondence}

Email: pnurhayati988@gmail.com Available online at http://ejurnalunsam.id/index.php/jsnbl/index 
SEUNEUBOK LADA

Jurnal Ilmu-Ilmu Sejarah, Sosial, Budaya dan Kependidikan, 7 (1), 2020: 53-64

ISSN : 2356-0770

e-ISSN : 2685-2705

\section{A. PENDAHULUAN}

Upaya melakukan perbaikan di bidang pendidikan menjadi tanggung jawab semua pihak, salah satunya yaitu guru. Sebagaimana dijelaskan oleh Hamalik (2004: 44) yang mengatakan bahwa guru bertanggung jawab melaksanakan kegiatan pendidikan di sekolah dalam arti memberikan bimbingan dan pengajaran kepada para siswa. Guru harus dapat melakukan suatu inovasi yang menyangkut tugasnya sebagai pendidik yang berkaitan dengan tugas mengajar siswa. Inovasi-inovasi yang dilakukan guru dalam tugasnya sebagai pendidik diharapkan mampu meningkatkan prestasi belajar siswa.

Untuk mencapai tujuan di atas, diperlukan strategi yang memadukan setiap komponen. Guru mata pelajaran IPS dituntut untuk mengembangkan kompetensi dan keprofesionalitas sesuai tuntutan dunia pendidikan yang berkembang pesat. Untuk itu, kreatifitas guru perlu dikedepankan sehingga dapat menumbuhkan karakter guru yang mampu mengembangkan dirinya dan bersama-sama bertanggung jawab terhadap profesinya demi kemajuan pendidikan di berbagai daerah pada umumnya. Dalam bidang pendidikan IPS, baik yang berbasis sekolah maupun berbasis masyarakat, tantangan yang dihadapi tidaklah sederhana. Tantangan yang mendesak yang perlu dijawab adalah terkait dengan upaya peningkatan mutu pendidikan. Salah satu variabel yang mempunyai kontribusi cukup besar terhadap baik buruknya kualitas pendidikan adalah unsur guru atau pendidik (Sapriya, 2009: 3).

Salah satu cara yang dapat ditempuh berkaitan dengan inovasi tugas mengajar guru adalah guru hendaknya mempunyai kemampuan melakukan variasi dalam penggunaan metode mengajarnya. Metode mengajar diartikan sebagai suatu cara atau teknik yang dipakai oleh guru dalam menyajikan materi ajar kepada siswa untuk mencapai tujuan pengajaran (Djamarah, 2004: 28). Guru hendaknya dapat memilih metode mengajar yang dianggap sesuai dengan materi yang hendak diajarkan. Hal ini dimaksudkan agar pengajaran khususnya mata pelajaran IPS dapat berlangsung secara efektif, efisien dan tidak membosankan.

Kenyataan di sekolah pelajaran IPS masih dianggap sebagai pelajaran nomor dua dan dianggap remeh oleh sebagian besar siswa. Kenyataan ini semakin diperburuk dengan metode mengajar yang dipakai oleh sebagian besar guru IPS masih memakai metode konvensional atau tradisional. Metode konvensional merupakan metode dimana guru memegang peranan utama dalam menentukan isi dan langkah-langkah dalam menyampaikan materi kepada siswa. Sehingga keaktifan siswa dalam mengikuti kegiatan belajar dan mengajar berkurang dan hanya bergantung pada guru. Akibatnya dalam mempelajari materi-materi IPS, siswa cenderung kurang semangat dan dianggap sebagai pelajaran yang membosankan. Hal tersebut terjadi pula di SMP Negeri 1 Peureulak Barat Kabupaten Aceh Timur. 
Nilai tes akhir belajar siswa kelas IX SMP Negeri 1 Peureulak Barat untuk mata pelajaran IPS pada kompetensi dasar menganalisis ketergantungan antarruang dilihat dari konsep ekonomi (produksi, distribusi, konsumsi, harga, pasar) dan pengaruhnya terhadap migrasi penduduk, transportasi, lembaga sosial dan ekonomi, pekerjaan, pendidikan, dan kesejahteraan masyarakat masih dikategorikan rendah dan belum mencapai Kriteria Ketuntasan Minimal (KKM) dimana dari 25 siswa, hanya 5 orang siswa atau $20 \%$ siswa yang hasil belajarnya mencapai batas nilai KKM yang ditetapkan sekolah yaitu 70 .

Sejalan dengan hal yang dipaparkan tersebut, maka dibutuhkan tindakan yang mampu mencari jalan keluarnya sehingga ketrampilan berfikir kreatif siswa yang bermuara pada peningkatan hasil belajar dapat meningkat. Usaha tersebut diantaranya dengan merubah strategi pembelajaran, termasuk didalamnya penggunaan metode atau model pembelajaran, dan hal lain yang dirasa perlu agar seluruh siswa terlibat dalam suasana pembelajaran serta mampu meningkatkan ketrampilan kreatif dalam mata pelajaran IPS dengan menggali sumber-sumber pembelajaran dari kehidupan nyata sehari-hari siswa.

Dalam pembelajaran di kelas kita sebagai guru harus membuat siswa merasa nyaman dan merasa senang terhadap materi yang sedang kita sampaikan. Atas dasar itulah perlu dicoba untuk diterapkan satu model pembelajaran yang dimungkinkan dapat meningkatkan kualitas belajar yang membuat siswa lebih aktif, kreatif berpikir kritis dan senang. Model pembelajaran itu adalah model pembelajaran kooperatif teknik Think Pair Share. Model pembelajaran kooperatif teknik Think Pair Share tersebut memiliki prosedur yang ditetapkan secara eksplisit dengan memberikan waktu kepada siswa agar lebih banyak berpikir untuk menjawab pertanyaan atau masalah dan menekankan saling membantu satu sama lain. (Lie, 2003: 56).

Dengan demikian, dalam model pembelajaran ini guru meminta siswa untuk memikirkan suatu topik, berpasangan dengan siswa lain, kemudian berbagi ide dengan seluruh kelas. Adanya kegiatan berpikir-berpasangan-berbagi dalam model pembelajaran memberi banyak keuntungan. Siswa secara individual dapat mengembangkan pemikirannya masing-masing karena adanya waktu berpikir (think time) sehingga kualitas jawaban siswa juga dapat meningkat.

Berdasarkan latar belakang masalah tersebut, maka penulis tertarik untuk mengangkat suatu penulisan makalah yang berjudul "Peningkatan Hasil Belajar IPS Melalui Model Pembelajaran Kooperatif Teknik Think Pair Share di Sekolah Menengah Pertama".

\section{B. KAJIAN TEORI}

1. Hakekat Belajar 
Belajar merupakan suatu proses di mana suatu tindakan muncul atau berubah karena adanya respons (jawaban) terhadap sesuatu situasi. Dengan belajar pengalaman atau pengetahuan terbentuk melalui interaksi dengan orang lain atau lingkungan (Uno, 2008: 19).

Konsep pembelajaran merujuk pada upaya penataan lingkungan (fisik, sosial, kultural dan psikologis atau spiritual) yang memberi suasana bagi tumbuh dan berkembangnya proses belajar. Jadi, bila dilihat dari individu yang belajar (pembelajar) proses belajar bersifat internal dan unik, sedang proses pembelajaran bersifat eksternal (datang dari luar diri) yang sengaja dirancang (Hasibuan dan Moerdjiono, 2005: 10).

Secara substansial, dapat disimpulkan bahwa belajar didefinisikan sebagai suatu proses yang ditandai dengan perubahan pada diri peserta didik, dan perubahan itu merupakan hasil belajar yang melibatkan segi jasmani serta rohani dan menghasilkan perubahan-perubahan dalam hal pengetahuan, pemahaman, ketrampilan, sikap, tingkah laku, serta semua aspek yang ada dalam individu dengan melibatkan dua unsur, yaitu jiwa dan raga.

\section{Kajian Materi Perdagangan Internasional \\ a. Pengertian Perdagangan Internasional}

Perdagangan internasional adalah perdagangan antara dua belah pihak yang berasal dari negara yang berbeda, berdasarkan pada perjanjian yang telah disepakati bersama. Pihak yang melakukan perdagangan ini dapat berupa individu, perusahaan atau pemerintah (Fathoni: 2015).

Perdagangan internasional didasari atas adanya perbedaan permintaan dan penawaran antarnegara. Perbedaan ini terjadi karena tidak semua negara memiliki dan mampu menghasilkan komoditas yang diperdagangkan, karena faktor-faktor alam negara tersebut tidak mendukung, seperti letak geografis dan kandungan buminya dan perbedaan pada kemampuan suatu negara dalam menyerap komoditas tertentu pada tingkat yang lebih efisien (Waluyo, 2007: 48).

Dengan demikian dapat disimpulkan bahwa perdagangan atau pertukaran berarti proses tukar-menukar yang dilakukan atas kehendak sukarela dari masingmasing pihak yang terlibat. Pada kenyataannya, dalam memenuhi kebutuhannya suatu negara belum mampu memproduksi barang sendiri tanpa menerima bantuan dari negara lain.

\section{b. Manfaat Perdagangan Internasional}

Perdagangan timbul karena salah satu atau kedua belah pihak melihat adanya manfaat/keuntungan tambahan yang bisa diperoleh dari perdagangan tersebut. Jadi, dorongan atau motif melakukan perdagangan adalah adanya kemungkinan diperolehnya manfaat tambahan tersebut. Ismawanto (2012) merincikan secara garis 
besar manfaat dari perdagangan internasional bagi suatu negara sebagaimana berikut ini.

1) Memperoleh sejumlah barang yang dibutuhkan.

2) Mendapatkan harga yang lebih murah daripada barang tersebut diproduksi sendiri.

3) Melaksanakan kegiatan ekspor dan impor.

4) Menambah devisa negara dan hasil ekspor.

5) Melakukan alih teknologi dari negara lain.

6) Mempercepat pertumbuhan dan pembangunan ekonomi.

7) Meningkatkan pendapatan nasional (Pendapatan Nasional Bruto).

Dalam mendulang segala bentuk suksesi dalam perdagangan internasional, tentu saja tidak terlepas daripada kebijakan perdagangan internasional. Kebijakan ini dimasudkan untuk memberi sitimulus keberhasilan serta menambah keuntungan bagi suatu negara (Waluyo, 2007: 49).

\section{c. Jenis-Jenis Perdagangan Internasional}

Bilamana dilihat dari kawasan-kawasan atau negara-negara yang terlibat dalam perdagangan internasional, maka perdagangan internasional dapat dibedakan menjadi 3 jenis. Hal ini sebagaimana diuraikan Fathoni (2015) berikut ini:

1) Perdagangan Bilateral

Perdagangan bilateral adalah perdagangan yang dilakukan antardua negara. Contohnya: dalam kerja sama perdagangan, Indonesia melakukan hubungan dengan salah satu negara lain

2) Perdagangan Regional

Perdagangan regional adalah perdagangan yang dilakukan oleh negara-negara yang berada dalam satu kawasan tertentu. Contohnya: Bentuk peran serta Indonesia dalam hubungan regional adalah sebagai salah satu negara pendiri Association of South East Asian Nation (ASEAN).

3) Perdagangan Multilateral

Perdagangan multilateral adalah perdagangan yang dilakukan oleh lebih dari dua negara yang tidak terbatas pada kawasan tertentu. Contohnya: Dalam hubungan multilateral, Indonesia berperan aktif dalam berbagai organisasi dunia seperti PBB, OPEC, APEC, dan WTO.

\section{Kajian Model Pembelajaran Kooperatif Teknik Think Pair Share}

Model pembelajaran kooperatif teknik Think Pair Share merupakan pembelajaran kelompok dimana siswa diberi kesempatan untuk berfikir mandiri dan saling membantu dengan teman yang lain.

\section{a. Pengertian Model Pembelajaran Kooperatif Teknik Think Pair Share}

Menurut Komalasari (2010: 42) menjelaskan bahwa model pembelajaran kooperatif teknik Think Pair Share dikembangkan oleh Frank Lyman dan kawankawannya dari Universitas Maryland yang mampu mengubah asumsi bahwa metode resitasi dan diskusi perlu diselenggarakan dalam setting kelompok kelas secara keseluruhan. Model pembelajaran kooperatif teknik Think Pair Share memberikan 
kepada parasiswa waktu untuk berfikir dan merespons serta saling bantu satu sama lain. Sedangkan menurut Ibrahim (2005: 89) menjelaskan bahwa Think Pair Share adalah suatu model pembelajaran kooperatif yang memberi siswa waktu untuk berfikir dan merespon serta saling bantu satu sama lain. Model pembelajaran kooperatif ini memperkenalkan ide "waktu berpikir atau waktu tunggu" yang menjadi faktor kuat dalam meningkatkan kemampuan siswa dalam merespons pertanyaan.

Dengan demikian dapat disimpulkan bahwa model pembelajaran kooperatif teknik Think Pair Share dapat meningkatkan kemampuan siswa dalam mengingat suatu informasi dan seorang siswa juga dapat belajar dari siswa lain serta saling menyampaikan idenya untuk didiskusikan sebelum disampaikan di depan kelas. Selain itu, penerapan model pembelajaran kooperatif teknik Think Pair Share juga dapat memperbaiki rasa percaya diri dan semua siswa diberi kesempatan berpartisipasi dalam kelas.

b. Langkah-Langkah Model Pembelajaran Kooperatif Teknik Think Pair Share

Penjelasan dari setiap langkah-langkah atau sintaks model pembelajaran kooperatif teknik Think Pair Share adalah sebagaimana dipaparkan (Nur, 2005: 81) berikut ini.

1) Tahap memberikan orientasi tentang permasalahan kepada siswa:

Awal pembelajaran dimulai dengan penggalian apersepsi sekaligus memotivasi siswa agar pada aktivitas pembelajaran. Pada tahap ini, guru juga menjelaskan aturan main serta menginformasikan batasan waktu untuk setiap tahap kegiatan.

2) Tahap think (berpikir secara individual)

Proses think pair share dimulai pada saat guru melakukan demonstrasi untuk menggali konsepsi awal siswa. Pada tahap ini, siswa diberi batasan waktu ("think time") oleh guru untuk memikirkan jawabannya secara individual terhadap pertanyaan yang diberikan. Dalam penentuannya, guru harus mempertimbangkan pengetahuan dasar siswa dalam menjawab pertanyaan yang diberikan.

3) Tahap pair (berpasangan dengan teman sebangku)

Pada tahap ini, guru mengelompokkan siswa secara berpasangan. Guru menentukan bahwa pasangan setiap siswa adalah teman sebangkunya. Hal ini dimaksudkan agar siswa tidak pindah mendekati siswa lain yang pintar dan meninggalkan teman sebangkunya. Kemudian, siswa mulai bekerja dengan pasangannya untuk mendiskusikan mengenai jawaban atas permasalahan yang telah diberikan oleh guru. Setiap siswa memiliki kesempatan untuk mendiskusikan berbagai kemungkinan jawaban secara bersama.

4) Tahap share (berbagi jawaban dengan pasangan lain atau seluruh kelas) Pada tahap ini, siswa dapat mempresentasikan jawaban secara perseorangan atau secara kooperatif kepada kelas sebagai keseluruhan kelompok. Setiap anggota dari kelompok dapat memperoleh nilai dari hasil pemikiran mereka.

5) Tahap penghargaan 
Siswa mendapat penghargaan berupa nilai baik secara individu maupun kelompok. Nilai individu berdasarkan hasil jawaban pada tahap think, sedangkan nilai kelompok berdasarkan jawaban pada tahap pair dan share, terutama pada saat presentasi memberikan penjelasan terhadap seluruh kelas.

Dengan demikian bahwa penerapan model pembelajaran kooperatif teknik Think Pair Share diharapkan siswa dapat mengembangkan keterampilan berfikir dan menjawab dalam komunikasi antara satu dengan yang lain, serta bekerja saling membantu dalam kelompok kecil.

\section{HASIL PENELITIAN}

Berdasarkan hasil penelitian yang telah dilakukan bahwa penerapan model pembelajaran kooperatif teknik Think Pair Share dapat meningkatkan hasil belajar siswa kelas IX semester II SMP Negeri 1 Peureulak Barat dalam pembelajaran IPS materi perdagangan internasional. Hal tersebut dapat dianalisis dan dibahas sebagai berikut:

\section{Pembahasan Hasil Belajar Kondisi Awal}

Pembelajaran IPS di kelas IX semester II SMP Negeri 1 Peureulak Barat masih menggunakan paradigma yang lama, dimana guru, memberikan pengetahuan kepada siswa yang pasif. Guru mengajar dengan metode konvensional yaitu ceramah, dan mengharapkan siswa duduk, diam, dengar, catat dan hafal. Proses pembelajaran pun menjadi monoton dan kurang menarik perhatian siswa. Setelah melakukan refleksi diri, peneliti mulai menyadari bahwa kondisi seperti itu tidak akan mampu meningkatkan hasil belajar siswa dalam memahami kompetensi pada mata pelajaran IPS.

Gambaran awal pada saat pelaksanaan pembelajaran yang dilakukan oleh guru di kelas IX semester II SMP Negeri 1 Peureulak Barat dimulai pada saat bel masuk berbunyi guru kemudian masuk ke dalam ruang kelas sampai akhir kegiatan belajar. Ketika guru masuk kedalam ruangan kelas dengan serempak siswa mengucapkan salam dan kemudian dijawab dengan salam pula. Berikutnya guru menyuruh anak-anak agar membaca do'a sebelum kegiatan belajar dimulai.

Dari hasil analisis terhadap kondisi awal ini diperoleh gambaran bahwa hasil belajar IPS siswa kelas IX semester II SMP Negeri 1 Peureulak Barat masih dikategorikan rendah. Rendahnya hasil belajar ini disebabkan oleh guru masih menggunakan pendekatan tradisional yang didominasi oleh lebih banyaknya penggunaan metode ceramah, dan pemberian tugas menulis kepada para siswanya. Akibatnya para siswa menjadi tidak bergairah dalam pembelajaran, jenuh dan tumbuhnya perasaan acuh tak acuh.

Kegiatan belajar mengajar yang kurang efektif berdampak pada hasil belajar yang diperoleh siswa kelas IX dalam pembelajaran IPS. Pada kondisi awal, hampir sebagian besar siswa belum mencapai Kriteria Ketuntasan Minimal (KKM) sebesar 70 dalam mempelajari materi tersebut. Nilai rata-rata siswa kelas IX pelajaran IPS rendah khususnya pada materi Perdagangan Internasional. Sebelum dilakukan tindakan, guru memberi tes dan ternyata dari sejumlah 25 siswa hanya terdapat 5 siswa (20\%) yang baru mencapai ketuntasan belajar sesuai dengan Kriteria 
Ketuntasan Minimal (KKM) yaitu sebesar 70. Sedangkan 20 siswa atau (80\%) belum mencapai Kriteria Ketuntasan Minimal. Perolehan nilai tertinggi pada kondisi awal adalah 80 dan yang terendah adalah 40 dengan rata-rata kelas 52. Dapat kita simpulkan bahwa kemampuan belajar siswa terbilang masih rendah. Nilai Rata-rata 52 dan persentase kululusan hanya mencapai $20 \%$.

Berdasarkan gambaran diatas, harus ada perbaikan dari berbagai aspek pembelajaran sebagai upaya untuk memperbaiki kekurangan tersebut diatas, maka akan diadakan tindakan dengan mengoptimalkan penggunaan model pembelajaran yang sesuai dengan pelajaran yang akan diajarkan. Adapun yang akan dioptimalkan adalah dengan menggunakan model pembelajaran kooperatif teknik Think Pair Share sebagai proses awal memperbaiki proses belajar mengajar.

\section{Pembahasan Hasil Belajar Siklus I}

Kegiatan pembelajaran pada siklus I sudah menunjukkan adanya perubahan. Namun demikian, hasil yang diperoleh pada siklus I ini masih belum begitu menggembirakan. Dari 25 orang siswa, 10 orang $(40 \%)$ sudah tuntas belajarnya, sedangkan selebihnya sebanyak 15 orang $(60 \%)$ belum tuntas belajarnya. Begitu pula dengan perolehan nilai tertinggi pada siklus I ini sebesar 90 dan nilai terendah sebesar 50. Nilai rata-rata hasil belajar 65,2. Hal ini menunjukkan belum tercapainya ketuntasan belajar minimum (KKM) sebesar 70. Dari data tersebut perlu adanya perbaikan/penyempurnaan pada siklus II nantinya.

Berdasarkan hasil pengamatan terhadap kegiatan siswa dalam siklus I ini dapat disimpulkan bahwa:

a. Siswa belum memahami langkah-langkah pembelajaran secara berpasangan sesuai model pembelajaran kooperatif teknik Think Pair Share.

b. Siswa belum mampu menjawab soal yang diberikan guru dengan baik melalui tugas-tugas yang diberikan.

c. Belum ada peningkatan yang signifikan pada siswa dalam mengerjakan tugas yang diberikan guru, mengerjakan LKS dengan benar, berani bertanya dan menjawab pertanyaan serta meningkatnya persentase ketuntasan belajar.

Selama kegiatan pembelajaran dalam penelitian berlangsung, peneliti dan observer mengamati jalannya proses pembelajaran untuk mengukur sejauh mana siswa mengalami perkembangan dan kemajuan didalam aktivitas belajarnya, untuk itu peneliti menyimpulkan hasil yang diperoleh dalam pengamatan tersebut kedalam kegiatan observasi yang dilakukan selama kegiatan proses pembelajaran berlangsung memberikan sebuah rangkaian informasi mengenai perkembangan belajar siswa tersebut.

Adapun yang menjadi kelemahan pada siklus ini yaitu pemahaman materi, pemberian motivasi dan bimbingan pelaksanaan diskusi secara berpasangan masih kurang maksimal. Berdasarkan analisis tersebut maka penelitian ini dilanjutkan ke siklus II.

\section{Pembahasan Hasil Belajar Siklus II}

Pada siklus ke II penelitian, perolehan nilai tertinggi hasil tes pada tahap pelaksanaan evaluasi adalah 100, dan terdapat 5 orang siswa yang mencapai angka 
tersebut, pada tahap siklus II ini nilai rata-rata siswa semua meningkat, dan dapat dikatakan bahwa pembelajaran menggunakan model pembelajaran kooperatif teknik Think Pair Share dapat meningkatkan hasil belajar siswa dalam pembelajaran IPS. Nilai terendah pada tahap siklus II ini adalah 60, siswa yang mendapatkan nilai 60 hanya 2 orang, jumlah ini hanya sebagian kecil saja dari keseluruhan jumlah siswa, dan persentasenya sekitar $8 \%$ dari keseluruhan siswa. Rata-rata nilai hasil tes adalah 82,4 dan persentase kelulusan $92 \%$. Hal ini membuktikan bahwa hasil belajar siswa meningkat mencapai hasil yang diharapkan.

Berdasarkan hasil pengamatan terhadap kegiatan siswa dalam siklus II ini dapat disimpulkan bahwa:

a. Pada siklus II ini, siswa sudah mampu untuk mengemukakan pendapat dan penjelasan tentang persoalan yang diberikan guru serta siswa sudah mampu untuk mendefinisikan masalah dan mendiagnosis masalah yang berhubungan dengan materi pembelajaran yang sedang dibahas.

b. Dari segi kerjasama kelompok secara berpasangan, terlihat dari beberapa siswa yang pasif pada siklus I mulai mengikuti kerja secara berpasangan dengan baik. Hal tersebut terlihat pada saat presentasi secara berpasangan. Saat guru memberikan kesempatan pada siswa lain untuk mengajukan pertanyaan, terlihat ada kemajuan pada siklus II. Hal ini terlihat lebih banyak siswa yang bertanya daripada pertemuan sebelumnya.

c. Kemampuan siswa dalam menganalisis masalah juga mengalami peningkatan, hal ini terlihat pada saat menyampaikan hasil kerja kelompok secara berpasangan, siswa mampu memahami persoalan yang diberikan, serta mampu menghubungkan suatu persoalan dengan materi pelajaran dan berusaha untuk memecahkan masalah serta mencari solusi dari permasalahan.

Hasil observasi putaran siklus II, secara garis besar pembelajaran dengan model pembelajaran kooperatif teknik Think Pair Share sudah dilaksanakan. Dalam penerapan model pembelajaran kooperatif teknik Think Pair Share ini telah mengalami peningkatan yang signifikan baik dari siswa maupun pelaksanaan pembelajarannya. Pada saat guru menjelaskan materi, respon siswa terhadap apa yang disampaikan guru mengalami kemajuan itu terlihat ketika guru menstimulus siswa dengan memberikan pertanyaan secara lisan, siswa yang kurang aktif pada siklus I sudah mulai berpartisipasi menjawab pertanyaan yang diberikan guru.

Dari hasil analisis yang dilakukan, ditarik kesimpulan bahwa nilai IPS siswa pada setiap siklus meningkat cukup baik. Hal ini dapat dilihat dari hasil jawaban siswa, sebagian besar siswa mampu menjawab soal-soal yang diberikan, begitu juga ketika kegiatan belajar secara berpasangan berlangsung, siswa mampu berdiskusi dengan baik untuk menentukan sebuah pemecahan masalah yang akan mereka gunakan untuk menjawab soal-soal yang diberikan guru.

Berikut gambaran peningkatan kegiatan siswa dan prestasi belajar siswa dari kondisi awal, siklus I dan siklus II. 
SEUNEUBOK LADA

Jurnal Ilmu-Ilmu Sejarah, Sosial, Budaya dan Kependidikan, 7 (1), 2020: 53-64

ISSN : 2356-0770

e-ISSN : 2685-2705

Tabel 1. Rekapitulasi Ketuntasan Belajar Kondisi Awal, Siklus I, dan II

\begin{tabular}{|l|l|c|c|c|c|c|c|}
\hline \multirow{2}{*}{ No } & \multirow{2}{*}{ Ketuntasan } & \multicolumn{5}{|c|}{ Jumlah Siswa } \\
\cline { 3 - 8 } & & \multicolumn{2}{|c|}{ Kondisi Awal } & \multicolumn{2}{|c|}{ Siklus I } & \multicolumn{2}{c|}{ Siklus II } \\
\cline { 3 - 8 } & & Jlh & Persen & Jlh & Persen & Jlh & Persen \\
\hline 1 & Tuntas & 5 & $20 \%$ & 10 & $40 \%$ & 23 & $92 \%$ \\
\hline 2 & Belum Tuntas & 20 & $80 \%$ & 15 & $60 \%$ & 2 & $8 \%$ \\
\hline \multicolumn{2}{c}{ Jumlah } & 25 & $100 \%$ & $100 \%$ & 25 & 25 & $100 \%$ \\
\hline
\end{tabular}

Berdasarkan data tabel di atas dapat digambarkan pada grafik diagram batang di bawah ini:

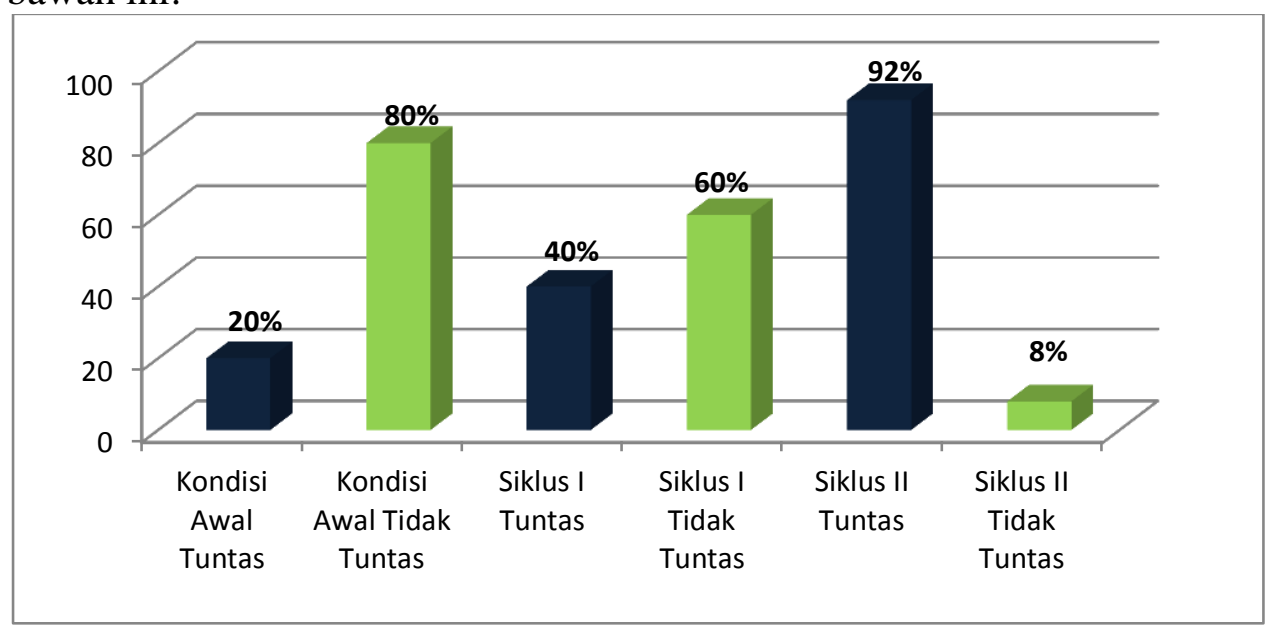

Gambar 3.1 Grafik Persentase Ketuntasan Belajar Kondisi Awal, Siklus I dan Siklus II

Perbandingan perolehan dari tes Kondisi awal, Siklus I dengan Siklus II dapat disajikan dalam tabel dan grafik berikut ini.

Tabel 3.2 Rekapitulasi Perolehan Nilai Kondisi Awal, Siklus I, dan II

\begin{tabular}{|l|l|c|c|c|}
\hline \multirow{2}{*}{ No } & \multirow{2}{*}{ Keterangan } & \multicolumn{3}{|c|}{ Nilai } \\
\cline { 3 - 5 } & & Kondisi Awal & Siklus I & Siklus II \\
\hline 1 & Nilai Tertinggi & 80 & 90 & 100 \\
\hline 2 & Nilai Terendah & 40 & 50 & 60 \\
\hline 3 & Jumlah Nilai & 1300 & 1630 & 2060 \\
\hline 4 & Nilai Rata-rata & 52 & 65,2 & 82,4 \\
\hline
\end{tabular}




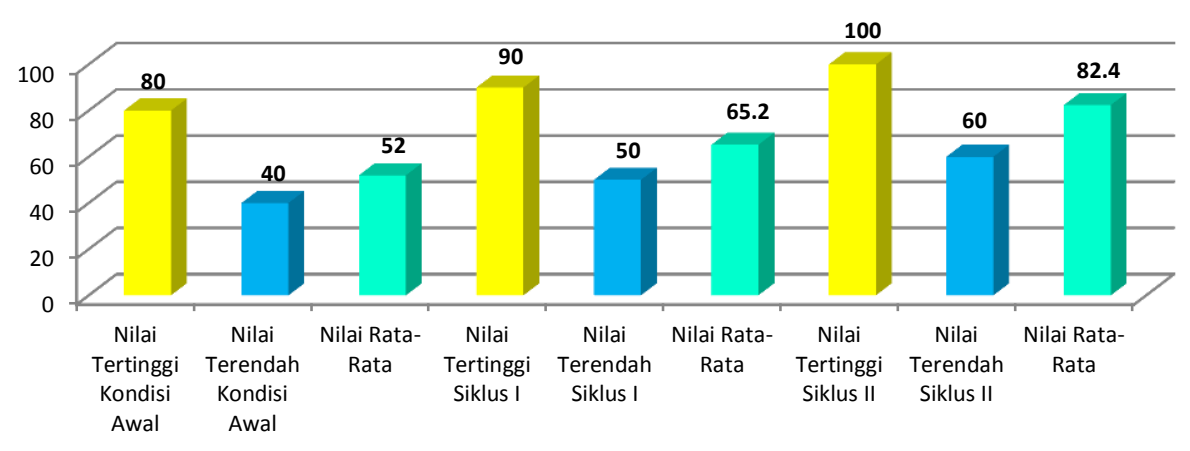

\section{Gambar 3.2 Grafik Perolehan Nilai Kondisi Awal, Siklus I, dan II}

Berdasarkan informasi data pada tabel dan grafik di atas, dapat disimpulkan bahwa perolehan nilai serta ketuntasan belajar siswa menunjukkan peningkatan yang berarti di tiap siklusnya. Pada kondisi awal, dari 25 siswa hanya terdapat 5 siswa (20\%) yang baru mencapai ketuntasan belajar sesuai dengan KKM yaitu sebesar 70. Sedangkan 20 siswa atau $(80 \%)$ belum mencapai Kriteria Ketuntasan Minimal. Perolehan nilai tertinggi pada kondisi awal adalah 80 dan yang terendah adalah 40 dengan rata-rata kelas 52. Dapat kita simpulkan bahwa kemampuan belajar siswa pada materi perdagangan internasional terbilang masih rendah, karena persentase kululusan hanya mencapai $20 \%$.

Pada pelaksanan siklus I pada proses pembelajaran dengan penerapan model pembelajaran kooperatif teknik Think Pair Share menunjukkan bahwa dari dari 25 orang siswa, 10 orang $(40 \%)$ sudah tuntas belajarnya, sedangkan selebihnya sebanyak 15 orang $(60 \%)$ belum tuntas belajarnya. Begitu pula dengan perolehan nilai tertinggi pada siklus I ini sebesar 90 dan nilai terendah sebesar 50. Nilai ratarata hasil belajar 65,2. Hal ini menunjukkan belum tercapainya Ketuntasan Belajar Minimal (KKM) sebesar 70.

Sedangkan hasil tindakan pada pelaksanan siklus II pada proses pembelajaran dengan model pembelajaran kooperatif teknik Think Pair Share dapat diketahui bahwa dari dari 25 orang siswa, 23 orang (92\%) sudah tuntas belajarnya, sedangkan selebihnya sebanyak 2 orang $(8 \%)$ belum tuntas belajarnya. Begitu pula dengan perolehan nilai tertinggi pada siklus I ini sebesar 100 dan nilai terendah sebesar 60 . Nilai rata-rata hasil belajar 65,2. Hal ini menunjukkan belum tercapainya Ketuntasan Belajar Minimal (KKM) sebesar 70.

Berdasarkan informasi data pada tabel di atas, dapat disimpulkan bahwa pembelajaran dengan menggunakan model pembelajaran kooperatif teknik Think Pair Share mampu meningkatkan hasil belajar IPS, khususnya pada materi "Perdagangan Internasional" di kelas IX SMP Negeri 1 Peureulak Barat. Dengan demikian penelitian dianggap berhasil dan berhenti pada siklus II. 


\section{KESIMPULAN}

Berdasakan hasil penelitian yang telah dilakukan selama dua siklus maka dapat ditarik beberapa kesimpulan sebagai berikut:

1. Perolehan nilai rata-rata hasil belajar siswa terhadap materi "Perdagangan Internasional", mengalami peningkatan yaitu pada kondisi awal sebesar 52 dan pada tindakan siklus I meningkat sebesar 65,2 sedangkan pada tindakan siklus II meningkat secara signifikan yaitu sebesar 82,4.

2. Skor kelulusan belajar siswa juga mengalami peningkatan yaitu pada kondisi awal hanya sebesar $20 \%$, setelah diberi tindakan pada siklus I menjadi $40 \%$ sedangkan pada siklus II ketuntasan belajar juga mengalami peningkatan yang signifikan yaitu sebesar $92 \%$.

3. Penerapan model pembelajaran kooperatif teknik Think Pair Share dapat meningkatkan motivasi belajar siswa dalam belajar IPS, hal ini ditunjukkan dengan antusias siswa yang menyatakan bahwa siswa tertarik dan berminat dengan model pembelajaran kooperatif teknik Think Pair Share sehingga dapat berpengaruh terhadap hasil belajar siswa.

\section{DAFTAR PUSTAKA}

Djamarah, S.B. 2004. Strategi Belajar Mengajar. Jakarta: Rineksa Cipta.

Fathoni, A. 2015. Perdagangan Internasional: Pengertian \& Manfaatnya. http://www.zonasiswa.com/2015/01/perdagangan-internasionalpengertian. html. Diakses pada tanggal 5 Juni 2017.

Hamalik, O. 2004. Proses Belajar Mengajar. Jakarta: PT. Bumi Aksara.

Hasibuan, J.J., dan Moerdjiono. 2005. Proses Belajar Mengajar. Bandung: Remaja Rosdakarya.

Ibrahim, M. 2005. Pembelajaran Kooperatif. Surabaya: UNESA.

Ismawanto. 2012. Pengertian, Faktor Pendorong dan Manfaat Perdagangan Internasional. http://www.ssbelajar.net/2012/03/perdaganganinternasional. html. Diakses pada tanggal 5 Juni 2017.

Komalasari, K. 2010. Pembelajaran Kontekstual; Konsep dan Aplikasi. Bandung: PT. Refika Aditama.

Lie, A. 2003. Cooperative Learning. Jakarta: Gramedia.

Nur, M. 2005. Pembelajaran Kooperatif. Surabaya: UNESA.

Poerwadarminto. 2004. Kamus Umum Bahasa Indonesia. Jakarta: Bina Ilmu.

Sapriya. 2009. Pendidikan IPS, Konsep dan Pembelajaran. Bandung: Remaja Rosda Karya.

Uno, H.B. 2008. Strategi Belajar Mengajar. Bandung: PT. Sinar Baru Algensindo.

Waluyo, I. 2007. Ekonomi Kontekstual. Surakarta: Mediatama. 